\begin{tabular}{|c|c|c|}
\hline 跣 & $\begin{array}{l}\text { İzmir İktisat Dergisi } \\
\text { İzmir Journal of Economics }\end{array}$ & \\
\hline $\begin{array}{l}\text { ISSN:1308-8173 } \\
\text { Gelis Tarihi: } 20.01 .2020\end{array}$ & $\begin{array}{ll}\text { E-ISSN: } 1308-8505 & \text { YIL: } 2021 \\
\text { Kabul Tarihi: } 06.05 .2021 & \text { Online Yavın: 02.08.2021 }\end{array}$ & $\begin{array}{l}\text { Cilt: } 36 \text { Sayı: } 1 \text { Sayfa: } 13-26 \\
\text { Doi: } 10.24988 / \text { ije. } 202136102\end{array}$ \\
\hline
\end{tabular}

\title{
The Impact of Electricity Consumption on Economic Growth in the European Union ${ }^{1}$ \\ Bayram AYDIN ${ }^{2}$ \\ Abstract
}

\begin{abstract}
In this study, the role of electricity on economic growth was investigated after the liberalization policies implemented in 1980 for the European Union. The main objective of the study is to present the relationship between electricity consumption and economic growth in the European Union and to propose economically efficient and feasible energy policies. For this purpose, the ARDL Bound Test Approach for the determination of the long-term relationship and Toda-Yamamoto Causality Analysis for the causality relation were used with the annual data for the period 1980-2014. The results show that electricity consumption has positive effect on economic growth in the long-run. Moreover, the results of Toda-Yamamoto Causality Analysis confirm the Growth Hypothesis, which argues that there is uni-directional causality relationship from electricity consumption to economic growth in the European Union.
\end{abstract}

Keywords: Electricity Consumption, Economic Growth, ARDL Bound Test Approach, Toda-Yamamoto Causality Analysis

Jel Codes: Q43, 013, E00

\section{Avrupa Birliği’nde Elektrik Tüketiminin Ekonomik Büyüme Üzerindeki Etkileri Özet}

Bu çalışmada 1980 yılında dünya genelinde uygulamaya konulan serbestleşme politikalarının sonrasında Avrupa Birliği'nin ekonomik büyümesinde elektrik enerjisinin rolü incelenmiștir. Çalışmanın temel amacl, Avrupa Birliği'nde elektrik tüketimi ile ekonomik büyüme arasındaki ilişsiyi ortaya koyarak iktisadi açıdan etkin ve uygulanabilir enerji politikaları önerilerinde bulunmaktır. Bu amaç doğrultusunda, 1980-2014 dönemindeki yıllık veriler ile uzun dönem ilişsisinin tespiti için ARDL Sınır Testi Yaklaşımı, nedensellik ilişsisi içinse Toda-Yamamoto Nedensellik Analizi kullanılmıştır. Ulaşılan sonuçlar uzun dönemde elektrik enerjisi tüketiminin ekonomik büyüme üzerinde pozitif etkisinin olduğunu göstermektedir. Ayrıca, Toda-Yamamoto nedensellik analizi sonuçları Avrupa Birliği'nde çevre iktisatçılarının desteklediği elektrik tüketiminden ekonomik büyümeye doğru tek yönlü nedensellik iliş̧kisi olduğunu savunan Büyüme Hipotezi'ni doğrulamaktadır.

Anahtar kelimeler: Elektrik Tüketimi, Ekonomik Büyüme, ARDL Sınır Testi Yaklaşımı, Toda-Yamamoto Nedensellik Analizi

Jel Kodu: Q43, 013, E00

\section{INTRODUCTION}

Energy was seen as an intermediate input in the production process because it was inexpensive and abundant in the early 1970s. Neoclassical Economists also accepted that energy was ineffective on economic growth. The energy shocks experienced in the 1970 s caused energy prices to rise and decline in economic growth rates. The 1973 Oil Crisis clearly demonstrated the role of energy in the production process. After the crisis, the relationship between energy and economic growth has become undeniable and this issue has been examined in many academic studies over the last half a century.

ATIF ÖNERisi (APA): Aydın, B. (2021). The Impact of Electricity Consumption on Economic Growth in the European Union. İzmir İktisat Dergisi, 36(1), 13-26. Doi:10.24988/ije.202136102

${ }^{1}$ This article was written with the help of Bayram AYDIN's master thesis which is named "The Relationship Between Electricity Consumption and Economic Growth: An Empirical Study on the European Union and Turkey" under the consultancy of Associate Professor Dr. Emre Güneșer BOZDAG at Gazi University Social Sciences Institute.

${ }^{2}$ Araș. Gör., Yozgat Bozok Üniversitesi, İktisadi ve İdari Bilimler Fakültesi, Merkez/YOZGAT

EMAIL: bayram.aydin@yobu.edu.tr ORCID: 0000-0003-4238-7779 


\section{B. AYDIN}

Ecological economics which arises after the living energy crisis has given great importance to energy. Ecological economics argues that energy is a production factor and therefore should be included in the production function. After understanding the role of energy in the production process, countries have been searching for new ways in which energy resources are more conducive and how to implement an energy policy. These quests are usually focused on energy restrictive policies and increasing efficiency in energy usage. The restrictive policies to be implemented in energy can generate various economic benefits and costs. For this reason, it is crucial for policy makers to determine the relationship between energy consumption and economic growth.

Substitution of energy sources instead of human and animal power began in the industrial revolution that emerged in the 18th and 19th centuries. Coal was the most important energy source used during this period. By the 1850s, oil usage increased rapidly and the oil age began in this period. With the discovery of Middle East oil resources, cheap oil supply and consumption reached its peak until the 1973 Oil Crisis. High oil prices during the crisis period have increased usage of nuclear energy and alternative energy sources. Countries have started to investments for electricity supply from these sources. Today, the use of electric energy which can be produced from many sources such as sun, wind, hydraulics, nuclear energy and biomass is increasing day by day with new investments and technologies.

The main objective of this study is to propose economically efficient and feasible energy policies by establishing the relationship between electricity consumption and economic growth in the European Union. For this purpose, the applied literature on electricity consumption and economic growth will be examined in this study and an econometric application will be made on the European Union economy after the liberalization policies implemented in 1980 in order to determine the nature and direction of the relationship.

There are some questions looking for answers in the literature on energy usage. Is energy necessary for economic growth? How do electric energy affect economic growth? In which resources are used in the production of electrical energy in the European Union? Are energy restrictive policies applicable? What kind of energy policy should be implemented in the economy? Such questions have been tried to be answered in this study.

There are four main hypotheses that explain the relationship between electricity consumption and economic growth, although there is no definitive view in the economic literature on the aspect of causality between electricity consumption and economic growth. These; The Growth Hypothesis which states that causality is unidirectional from electricity consumption to economic growth, Conservation Hypothesis which expresses the unidirectional condition from economic growth to electrical consumption, Feedback Hypothesis which expresses the bidirectional causality condition, and Neutrality Hypothesis which expresses the absence of causality between variables.

\section{ELECTRICAL ENERGY OUTLOOK IN THE EUROPEAN UNION}

The European Union (EU) today uses the most renewable energy sources in the production of electricity. Renewable energy sources although the most widely used fuel in electricity supply in the EU, renewable energy sources were used in small amounts in the 1990s. While 327,8 terawatt/hour (TWh) electricity was generated from renewable energy sources in electricity generation in 1990, it reached 931,2 TWh in 2015. Over the past 25 years, the use of renewable energy sources in the EU's electricity supply has increased threefold. Likewise, solid fuels and oil which are used little in electricity production in the EU at the present time, they were the most widely used energy sources in the $1990 \mathrm{~s}$. In the past 25 years, renewable energy sources have been 
replaced by solid fuels and oil. This shows that there has been a radical change in the electricity sector in the EU. Figure 1 shows the production of electricity in the EU according to the energy sources that change to years (European Commission, 2019).

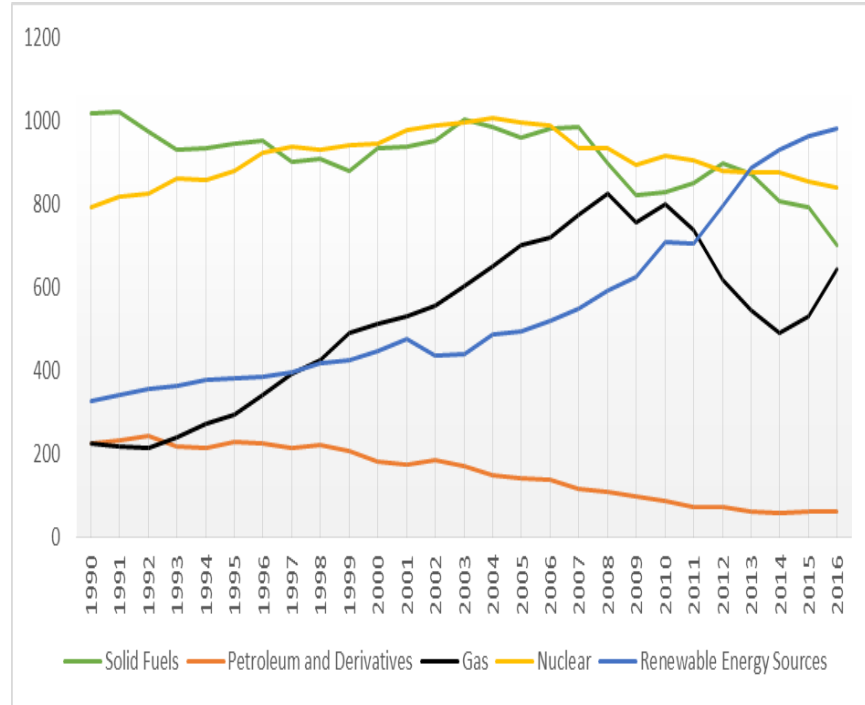

Figure 1: Gross electricity generation by EU energy sources for the period of 1990-2016

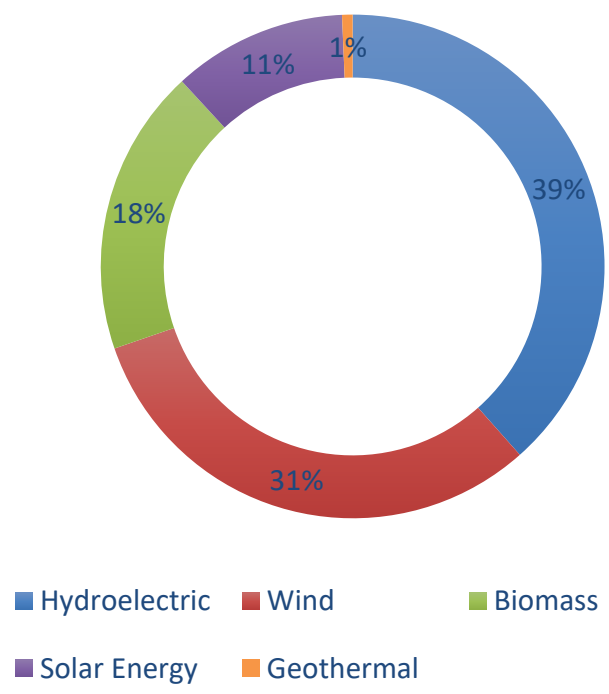

Figure 2: EU renewable energy sources used in electricity generation in 2015

The use of renewable energy sources has increased continuously over the years and today it has become the most used energy source in the EU. Figure 2 shows the magnitude of the renewable energy sources used in electricity generation in the EU. Wind and hydroelectric energy are the most widely used renewable energy sources in the EU. The usage of renewable energy sources in electricity generation and the reduction of solid fuels usage which have positive effect to considering the environmental impacts.

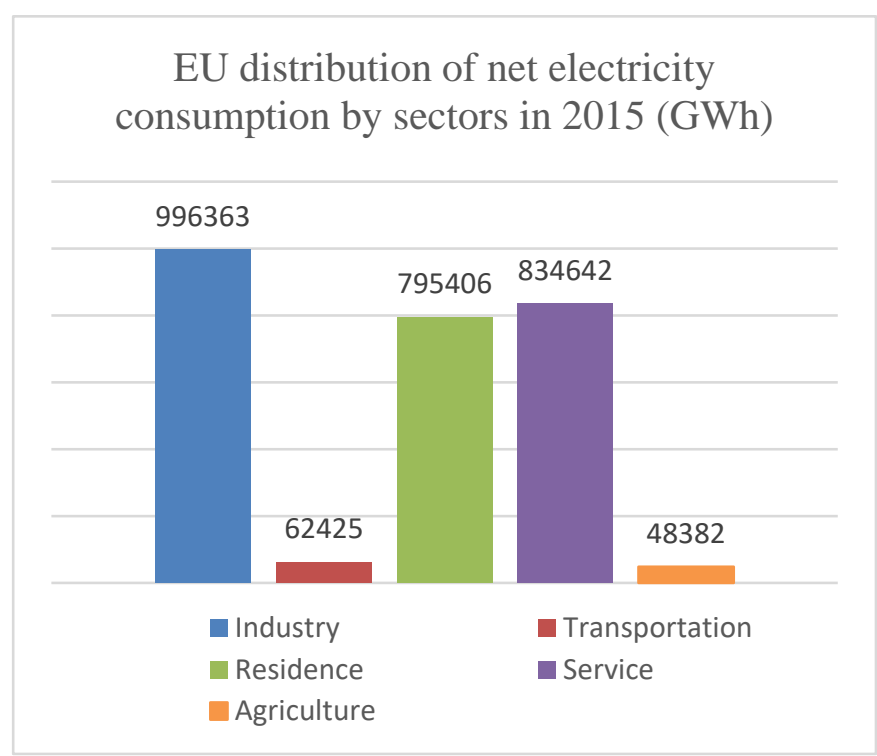

Figure 3: EU distribution of net electricity consumption by sectors in 2015

In developed countries, electricity is used in industrial sector in large proportions. In the EU, industry is the most electricity-consuming sector with the rate of $36,35 \%$. The service sector which is also involved in economic activities in the EU, is the second largest group to use electricity with a rate of $30.45 \%$ (International Energy Agency (IEA), 2017).

\section{LITERATURE REVIEW}

The causality relationship between electricity consumption and economic growth is an important area of research for many years. As researches include different countries, different time periods, different methods and variables, the findings obtained in the literature of economics have created differences and no common result has been achieved. In addition to the different econometric methods, there are different time intervals, data sets, models and different country characteristics in the studies (Payne, 2010). For this reason, a clear environment or energy policy has not been developed yet. 


\section{B. AYDIN}

There are four main hypotheses that explain the relationship between electricity consumption and economic growth, although there is no definitive view in the economic literature on the aspect of causality between electricity consumption and economic growth. These; The Growth Hypothesis which refers to the fact that causality is unidirectional from the consumption of electricity to the economic growth, Conservation Hypothesis which refers to the fact that causality is unidirectional from economic growth to electricity consumption, the Feedback Hypothesis which expresses the fact that there is bidirectional causality between variables and the Neutrality Hypothesis which refers to the fact that there is no causality between variables.

It is possible to divide empirical studies into two categories such as the studies for many countries and the studies for one country. Although there are many studies in this area, the results are different according to the countries and regions. The results obtained in the studies and the applied methods are presented in Table 1 and Table 2.

In the preliminary studies which is observed that cointegration and standard Granger Causality Tests are mostly used in literature. New analyses have emerged with the development of econometric methods. The causality relationship between economic growth and electricity consumption has been re-examined under relatively more advanced approaches such as ARDL Border Test, TodaYamamoto Causality Test, panel cointegration and panel causality tests.

The literature between electricity consumption and economic growth gained a great speed after Ghosh's study. Ghosh performed the study on India in the period 1950-1997. Ghosh used Johansen Cointegration analysis and Granger causality Analysis with per capita electricity consumption and per capita real GDP variables. Ghosh found that the variables were cointegrated and that there was a one-way causality towards electricity consumption from economic growth. This milestone study has increased researches for many regions and countries in the relevant areas (Ghosh, 2002). The general characteristics of the literature are as follows;

The long-term relationship between variables and causality was studied in almost all of the literature. These examinations were used cointegration and causality tests.

$>$ Based on preliminary studies, Johansen Cointegration and standard Granger Causality Tests are mostly used in studies. However, the current literature has adopted relatively more complex approaches such as ARDL Border Test, Toda-Yamamoto causality test, panel cointegration and panel causality tests with the development of econometric methods.

$>$ It has been concluded that there is a longterm relationship between electricity consumption and economic growth in the majority of the studies.

$>$ The results of causality analysis vary according to countries and regions. In the studies, there was no joint conclusion on the direction of causality. In the context of the results, four separate hypotheses have been developed in the literature.

$>$ In the majority of the studies findings proving the one-way causation relationship between electricity consumption and economic growth and supporting the Growth Hypothesis. In addition, some studies supported the Conservation Hypothesis and Feedback Hypothesis. However, studies supporting the Hypothesis of Neutrality are very rare.

> As a variable; real GDP per capita and per capita electricity consumption are used more than total real GDP and total electricity consumption.

Most of the studies constitute time series analysis. Panel data analysis and cross section data analysis are also among the used methods in the literature. 
Ciarreta and Zarraga (2008) study on 12 European countries is about studying the effect of electricity consumption of EU countries on economic growth as in this study. As in this study, it was found that the variables were longterm related. However, the study period (19702004) evaluates pre-1980 period and post1980 period together. Before 1980, inward import substitution policies were followed in developing countries and all around the world. After 1980, import substitution and Keynesian views were abandoned and the world was in the process of globalization. After 1980, developing countries started to open up and adopted the strategy of export-based industrialization. Therefore, studies should be evaluated separately before and after 1980 .

Table 1: Literature on the relationship between electricity consumption and economic growth for single-country studies

\begin{tabular}{|c|c|c|c|}
\hline $\begin{array}{l}\text { Author's Surname, } \\
\text { Year }\end{array}$ & $\begin{array}{c}\text { Country and } \\
\text { Period }\end{array}$ & Method & Obtained Results \\
\hline Ghosh (2002) & $\begin{array}{c}\text { India } \\
1950-1997 \\
\end{array}$ & $\begin{array}{c}\text { Johansen-Juselius Cointegration Analysis } \\
\text { and Granger Causality Analysis }\end{array}$ & $\begin{array}{l}\text { A long term relationship was found between the } \\
\text { variables. The direction of causality; GDP } \rightarrow \text { EC. }\end{array}$ \\
\hline Shiu and Lam (2004) & $\begin{array}{l}\text { China } \\
1971-2000\end{array}$ & $\begin{array}{c}\text { Johansen Cointegration Analysis, ECM, } \\
\text { Granger Causality Analysis }\end{array}$ & $\begin{array}{c}\text { Real GDP and electricity consumption are } \\
\text { cointegrated and there is unidirectional causality } \\
\text { (EC } \rightarrow \text { GDP). }\end{array}$ \\
\hline Nişancl (2005) & $\begin{array}{c}\text { Turkey } \\
1970-2003\end{array}$ & $\begin{array}{l}\text { Johansen Cointegration Analysis and } \\
\text { VECM }\end{array}$ & $\begin{array}{c}\text { National income and electricity consumption are } \\
\text { cointegrated and there is one way causality between } \\
\text { them (EC } \rightarrow \text { GDP). }\end{array}$ \\
\hline $\begin{array}{l}\text { Narayan and Smyth } \\
\text { (2005) }\end{array}$ & $\begin{array}{c}\text { Australia } \\
1966-1999\end{array}$ & $\begin{array}{l}\text { Unit Root Analysis by Zivot-Andrews } \\
\text { Structural Fracture Test, Cointegration } \\
\text { and Granger Causality } \\
\end{array}$ & $\begin{array}{l}\text { Per-capita real GDP and per capita electricity } \\
\text { consumption are cointegrated and there is one way } \\
\text { causality among them (GDP } \rightarrow \mathrm{EC}) \text {. }\end{array}$ \\
\hline Yoo (2005) & $\begin{array}{c}\text { Korea } \\
1970-2002\end{array}$ & CUSUM Test, Cointegration and ECM & $\begin{array}{l}\text { There is bi-directional causality between the } \\
\text { variables of GDP and Electricity Consumption } \\
\text { (GDP↔EC). }\end{array}$ \\
\hline $\begin{array}{l}\text { Ciarreta and Zarraga } \\
\text { (2007) }\end{array}$ & $\begin{array}{c}\text { Spain } \\
1971-2005\end{array}$ & $\begin{array}{l}\text { Toda and Yamamoto, Dolado and } \\
\text { Lütkepohl, Granger Causality Analysis }\end{array}$ & $\begin{array}{l}\text { Three different causality analyses yielded the same } \\
\text { results. One way causality has been identified } \\
\text { (GDP } \rightarrow \text { EC). }\end{array}$ \\
\hline Tang (2008) & $\begin{array}{c}\text { Malaysia } \\
1972: 1-2003: 4\end{array}$ & $\begin{array}{l}\text { ARDL Bound Test Analysis and Causality } \\
\text { Analysis }\end{array}$ & $\begin{array}{c}\text { For Malaysia, it has been found that the variables } \\
\text { are not co-integrable. So, there is no long-term } \\
\text { relationship. }\end{array}$ \\
\hline Akinlo (2009) & $\begin{array}{c}\text { Nigeria } \\
1980-2006\end{array}$ & Johansen Cointegration Analysis, ECM & $\begin{array}{l}\text { One-way causality was found between the variables } \\
\qquad(E C \rightarrow G D P) .\end{array}$ \\
\hline Kayhan, et al. (2010) & $\begin{array}{c}\text { Romania } \\
\text { 2001:01 -2010:01 } \\
\end{array}$ & $\begin{array}{l}\text { Dolado-Lütkepohl, Tada- Yamamoto and } \\
\text { traditional Granger Causality Tests }\end{array}$ & $\begin{array}{l}\text { One-way causality was determined by } 3 \text { different } \\
\text { methods (EC } \rightarrow \text { GDP). }\end{array}$ \\
\hline Atif and Siddiqi (2010) & $\begin{array}{l}\text { Pakistan } \\
1971-2007\end{array}$ & $\begin{array}{l}\text { Engle-Granger Cointegration Analysis, } \\
\text { Granger Causality Test }\end{array}$ & $\begin{array}{c}\text { There was no relationship between variables in the } \\
\text { long term. However, one-way causality has been } \\
\text { identified (EC } \rightarrow \text { GDP). }\end{array}$ \\
\hline $\begin{array}{l}\text { Shahbaz, Tang and } \\
\text { Shabbir, (2011) }\end{array}$ & $\begin{array}{l}\text { Portugal } \\
1971-2009\end{array}$ & $\begin{array}{l}\text { Johansen Cointegration Analysis, VECM, } \\
\text { Granger Causality Analysis }\end{array}$ & $\begin{array}{l}\text { The variables are cointegrated and long-term bi- } \\
\text { directional causality (GDP } \rightarrow \text { EC) and short-term } \\
\text { one-way causality (GDP } \rightarrow \text { EC) have been identified. }\end{array}$ \\
\hline Hamdi and Sbia (2012) & $\begin{array}{l}\text { Bahrain } \\
\text { 1980-2008 }\end{array}$ & $\begin{array}{l}\text { Johansen Cointegration Analysis, ECM, } \\
\text { Granger Causality Analysis }\end{array}$ & $\begin{array}{c}\text { Variables are cointegrated. Long-term bi-directional } \\
\text { causality (GDP } \rightarrow \text { EC) and short-term one-way } \\
\text { causality (GDP } \rightarrow \text { EC) have been detected. }\end{array}$ \\
\hline $\begin{array}{c}\text { Bélaïd and } \\
\text { Abderrahmani (2013) }\end{array}$ & $\begin{array}{c}\text { Algeria } \\
1971-2010\end{array}$ & $\begin{array}{c}\text { Zivot-Andrews Structural Breakdown } \\
\text { Unit Root Test, Gregory-Hansen and } \\
\text { Johansen Cointegration and VECM } \\
\end{array}$ & $\begin{array}{l}\text { The results show that there is a long-run } \\
\text { relationship between the variables. Furthermore, bi- } \\
\text { directional causality was detected (GDP↔EC). }\end{array}$ \\
\hline Shahbaz, et al. (2014) & $\begin{array}{l}\text { United Arab } \\
\text { Emirates } \\
1975-2011\end{array}$ & $\begin{array}{l}\text { Zivot-Andrews Structural Breakdown } \\
\text { Unit Root Test, ARDL Bound Test }\end{array}$ & Variables are related to long term. \\
\hline $\begin{array}{l}\text { Peter Sekantsi and } \\
\text { Motlokoa (2015) }\end{array}$ & $\begin{array}{c}\text { Uganda } \\
1982-2013\end{array}$ & $\begin{array}{l}\text { Johansen Cointegration Analysis and } \\
\text { VECM }\end{array}$ & $\begin{array}{l}\text { Cointegration was found between the variables and } \\
\text { long-term bi-directional (GDP } \rightarrow \text { EC) and short-term } \\
\text { one-way (GDP } \rightarrow \text { EC) causality were determined. }\end{array}$ \\
\hline $\begin{array}{l}\text { Ikegami and Wang } \\
\text { (2016) }\end{array}$ & $\begin{array}{l}\text { Japan and } \\
\text { Germany } \\
\text { 1996:04-2015:02 }\end{array}$ & $\begin{array}{l}\text { ARDL Bound Test, CUSUM Test and } \\
\text { Granger Causality Analysis }\end{array}$ & $\begin{array}{l}\text { There is a significant cointegration relationship } \\
\text { between total electricity consumption and real GDP. } \\
\text { There is one-way causality (EC } \rightarrow \text { GDP) in Japan, and } \\
\text { the opposite (GDP } \rightarrow \text { EC) causality in Germany. }\end{array}$ \\
\hline Bah and Azam (2017) & $\begin{array}{c}\text { South Africa } \\
1971-2012 \\
\end{array}$ & $\begin{array}{l}\text { Toda and Yamamoto Causality Analysis } \\
\text { and ARDL Bound Test }\end{array}$ & $\begin{array}{l}\text { The variables are cointegrated, but there is no } \\
\text { causality relationship between them (GDP-EC). }\end{array}$ \\
\hline
\end{tabular}

Note: GDP: Growth, EC: Electricity Consumption, ECM: Error Correction Model, VECM: Vector Error Correction Model, $\leftrightarrow$ : bidirectional causality relation, $\rightarrow$ : one-way causality relation, - : no causality relation. 


\section{B. AYDIN}

Table 2: Literature on the relationship between electricity consumption and economic growth for regional studies

\begin{tabular}{|c|c|c|c|}
\hline $\begin{array}{l}\text { Author's Surname, } \\
\text { Year }\end{array}$ & $\begin{array}{l}\text { Country and } \\
\text { Period }\end{array}$ & Method & Obtained Results \\
\hline Yoo (2006) & $\begin{array}{l}\text { ASEAN Countries } \\
\text { 1971-2002 }\end{array}$ & $\begin{array}{l}\text { Time Series Analysis, Engle-Granger } \\
\text { Cointegration Analysis and Granger } \\
\text { Causality Analysis }\end{array}$ & $\begin{array}{l}\text { There are two-way causality (GDP } \rightarrow \mathrm{EC} \text { ) in Malaysia } \\
\text { and Singapore, and one-way causality (GDP } \rightarrow \mathrm{EC} \text { ) in } \\
\text { Indonesia and Thailand. }\end{array}$ \\
\hline Wolde-Rufael (2006) & $\begin{array}{l}17 \text { African } \\
\text { Countries } \\
1971-2001\end{array}$ & $\begin{array}{l}\text { Time Series Analysis, Toda and } \\
\text { Yamamoto Causality Analysis, ARDL } \\
\text { Model }\end{array}$ & $\begin{array}{c}\text { A long-term relationship has been identified for } 9 \\
\text { countries and for } 12 \text { countries causality was } \\
\text { determined. }\end{array}$ \\
\hline Squalli (2007) & $\begin{array}{l}11 \text { OPEC countries } \\
1980-2003\end{array}$ & $\begin{array}{c}\text { Pesaran Bound Test, Unrestricted } \\
\text { ECM, Toda and Yamamoto Causality } \\
\text { Analysis }\end{array}$ & $\begin{array}{l}\text { The long-term relationship between the variables was } \\
\text { determined for all OPEC countries. Two-way causality } \\
\text { for five countries (Iran, Nigeria, Qatar, Saudi Arabia } \\
\text { and United Arab Emirates) and one-way causality for } \\
\text { six countries (Algeria, Indonesia, Iraq, Kuwait, Libya } \\
\text { and Venezuela) were determined. }\end{array}$ \\
\hline Böhm (2008) & $\begin{array}{l}15 \text { European } \\
\text { Countries } \\
1978-2005\end{array}$ & $\begin{array}{c}\text { Panel Cointegration and Causality } \\
\text { Analysis }\end{array}$ & Results differ according to studied the countries. \\
\hline $\begin{array}{l}\text { Ciarreta and Zarraga } \\
\quad(2010)\end{array}$ & $\begin{array}{l}\text { 12 European } \\
\text { Countries } \\
1970-2007\end{array}$ & $\begin{array}{c}\text { Panel Cointegration and Causality } \\
\text { Analysis, trivariate VECM estimated by } \\
\text { system GMM }\end{array}$ & $\begin{array}{l}\text { The results show evidence of a long-run equilibrium } \\
\text { relationship between series and strong causality from } \\
\text { electricity consumption to GDP (EC } \rightarrow \text { GDP). }\end{array}$ \\
\hline $\begin{array}{l}\text { Narayan, Narayan and } \\
\quad \text { Prasad (2008) }\end{array}$ & $\begin{array}{c}\text { G7 Countries } \\
1970-2002\end{array}$ & Structural VAR & $\begin{array}{c}\text { All countries except the USA, electricity consumption } \\
\text { has been found to be very effective on economic } \\
\text { growth. }\end{array}$ \\
\hline Ağır and Kar (2010) & $\begin{array}{c}\text { Turkey's } 81 \\
\text { provinces in } 2000\end{array}$ & Cross Section Data Analysis & $\begin{array}{l}\text { Per Capita Real GDP is positively affected by Per } \\
\text { Person Electricity Consumption. }\end{array}$ \\
\hline $\begin{array}{l}\text { Acaravci and Ozturk } \\
\qquad(2010)\end{array}$ & $\begin{array}{l}15 \text { Transition } \\
\text { Country } \\
1990-2006\end{array}$ & $\begin{array}{l}\text { Pedroni Panel Cointegration Analysis, } \\
\text { ECM }\end{array}$ & $\begin{array}{l}\text { Cointegration and causality did not determined } \\
\qquad \text { (GDP-EC). }\end{array}$ \\
\hline $\begin{array}{l}\text { Ergün and Atay Polat } \\
\qquad(2015)\end{array}$ & $\begin{array}{l}30 \text { OECD Countries } \\
1980-2010\end{array}$ & Panel Cointegration and Panel VECM & $\begin{array}{c}\text { It is concluded that the variables have the } \\
\text { cointegration relation and the bidirectional causality } \\
\text { relation (GDP } \rightarrow \mathrm{EC} \text { ). }\end{array}$ \\
\hline $\begin{array}{l}\text { Osman, Gachino and } \\
\text { Hoque (2016) }\end{array}$ & $\begin{array}{c}\text { GCC Countries } \\
1975-2012\end{array}$ & $\begin{array}{c}\text { Westerlund's and Pedroni } \\
\text { Cointegration Analysis, Hausman Test, } \\
\text { Panel ECM and Granger Causality } \\
\text { Analysis }\end{array}$ & $\begin{array}{l}\text { Long-term relationship and two-way causality were } \\
\text { found (GDP↔EC). }\end{array}$ \\
\hline
\end{tabular}

Note: GDP: Growth, EC: Electricity Consumption, ECM: Error Correction Model, VECM: Vector Error Correction Model, $\leftrightarrow$ : bidirectional causality relation, $\rightarrow$ : one way causality relation, - - no causality relation.

Another missing part of the literature is that authors included the analysis in the period of the oil crisis in 1973. In most studies, the 1970s were included in the analysis. However, since the crisis may cause structural breakages in the series, the years of the crisis should not be included in the analysis.

In addition, Johansen Cointegration and Standard Granger Causality tests are frequently used in the literature. Instead of these analyses, more recent analysis will give healthier results.
In this study, the 1980s and the following years were included in the analysis because of the crisis in the 1970s and the change of economic strategies after 1980. Also, ARDL Bound Test and Toda-Yamamoto Causality Test were preferred because of the more current econometric methods.

\section{METHODOLOGY}

In this study, the ARDL Bound Test Approach which was introduced at the end of the literature in order to determine the long-term relationship between the variables and TodaYamamoto Causality Test which determine the 
causal relationship between the variables were preferred because of they are more current than conventional methods. Another reason is that the Toda-Yamamoto Causality Test and the ARDL Bound Test have not been applied for the European Union before in the literature.

\subsection{ARDL Bound Test Approach}

In a regression analysis using a time series data, this model is called a distributed lag model if the model independent variables have not only the current period values but also the lagged values at the same time. If the model contains one or more lagged values in its dependent variable, this model is also called the autoregressive model (Gujarati and Porter, 2009).

$$
\begin{aligned}
& Y_{t}=a+B_{0} X_{t}+B_{1} X_{t-1}+B_{2} X_{t-2}+u_{t} \\
& Y_{t}=a+B X_{t}+\lambda Y_{t-1}+u_{t}
\end{aligned}
$$

The equation 1 represents the distributed lag model and the equation 2 represents the autoregressive model.

The ARDL approach is testing the existence of a cointegration relation between variables. The Engle-Granger approach assumes that the series should be stationary at the same level. In the ARDL approach the series should be stable at level (I (0)) or first difference (I (1)) while not assuming that the series should be stationary at the same level. The most important advantage of this approach is that it can be applied regardless of whether the variables used in the analysis are I(0) or I(1). For this reason, an inference can be made without having to know the cointegration states of the variables. The second advantage is that it has better statistical properties than the Engle-Granger method because it uses the unconstrained error correction model (UECM). In addition, the ARDL method can be applied in cases where the number of observations is small (Pamuk and Bektaş, 2014).

The UECM equation used in the ARDL approach is shown in Equation 3.

$$
\begin{aligned}
\Delta Y_{t}=B_{0} & +B_{1} Y_{t-1}+B_{2} X_{t-1}+\sum_{i=1}^{p} B_{3 i} \Delta Y_{t-i} \\
& +\sum_{i=0}^{p} B_{4 i} \Delta X_{t-i}+\varepsilon
\end{aligned}
$$

In equation 3 , $p$ value indicates the appropriate lag length. The lag lengths to be added to the model are determined by information criteria such as HQ (Hannan-Quinn), AIC (Akaike info criterion) and SIC (Schwarz Info Criterion). Following the determination of the delay length, the hypothesis $H_{0}=B_{1}=B_{2}=0$ is tested using the F-statistic. Two groups of asymptotic critical limits are used in the ARDL bound test approach. If the calculated Fstatistic exceeds the critical value upper limit, the basic hypothesis $H_{0}$ is rejected and the variables are interpreted as cointegrated. If the F statistic value falls below the lower bound, then $H_{0}$ is assumed and the variables are said to be non-cointegrated. A clear deduction can not be made if the calculated statistical value remains within the limits (Alper and Alper, 2017).

After determining the cointegration relation by the bound test, the ARDL model is established in order to determine the long term relation between the variables with the help of Equation 4.

$Y_{t}=a_{0}+\sum_{i=1}^{n} a_{1 i} Y_{t-i}+\sum_{i=0}^{m} a_{2 i} X_{t-i}+\varepsilon_{t}$

At the latest stage of the ARDL bound test approach, the ARDL model for equality 5 is estimated for the short term relationship between variables.

$$
\begin{gathered}
\Delta Y_{t}=a_{0}+\sum_{i=1}^{n} a_{1 i} \Delta Y_{t-i}+\sum_{i=0}^{m} a_{2 i} \Delta X_{t-i} \\
+\varphi H D T_{t-1}+\varepsilon_{t}
\end{gathered}
$$

The $H D T_{t-1}$ variant in Equation 5 , which is expressed as error correction term. It is the value of the previous series of residuals obtained from the long-term ARDL model. The $\varphi$ coefficient of the error correction term 
indicates how much of the short-term imbalance can be rectified in the long run (Pamuk and Bektaş, 2014).

\subsection{Toda-Yamamoto Causality Analysis}

The Toda-Yamamoto causality test is based on the Vector Autoregressive (VAR) model. In the analysis, a VAR model with an $\left(\mathrm{m}+d_{\max }\right)$ dimension is estimated after determining the appropriate lag length $(\mathrm{m})$ of the VAR model and the maximum stagnation degree $\left(d_{\max }\right)$ of the used series. The estimated VAR $\left(\mathrm{m}+d_{\max }\right)$ model in the Toda-Yamamoto causality approach consists of equations 6 and equality 7 (Toda and Yamamoto, 1995).

$$
\begin{gathered}
Y_{t}=\omega+\sum_{i=1}^{m} a_{1 i} X_{t-i}+\sum_{i=1}^{m} B_{1 i} Y_{t-i}+\sum_{j=m+1}^{d m a x} \delta_{1 i} X_{t-i} \\
+\sum_{j=m+1}^{d m a x} \theta_{1 i} Y_{t-i}+\varepsilon_{1 t} \\
X_{t}=\varphi+\sum_{i=1}^{m} a_{2 i} X_{t-i}+\sum_{i=1}^{m} B_{2 i} Y_{t-i}+\sum_{j=m+1}^{d \max } \delta_{2 i} X_{t-i} \\
+\sum_{j=m+1}^{d m a x} \theta_{2 i} Y_{t-i}+\varepsilon_{2 t}
\end{gathered}
$$

The appropriate lag length (m) can be determined with the aid of information criteria, and the maximum degree of integration $\left(d_{\max }\right)$ can be determined with unit root tests. The $H_{0}: a_{1 i}=0$ and $H_{0}: a_{2 i}=0$ hypotheses are tested using the regulated WALD test statistic to determine the existence of the mutual causality relationship between variables. If the calculated MWALD test statistic value is greater than the degree of freedom $X^{2}$ table value, the above hypotheses are rejected (Gazel, 2017).

\section{MODEL AND DATA SET}

In this study, the relationship between economic growth and electricity consumption was investigated with the model expressed in equation 8.

$$
L O G G D P_{t}=a_{0}+a_{1} L O G E L C_{t}+\varepsilon_{t}
$$

In the study, data will be employed on an annual basis between 1980 and 2014. The datas are obtained from the World Bank. The natural logarithm for electricity consumption is given in kilowatt/hour (kWh) per person, and the natural logarithm for economic growth is taken as the time series of GDP in 2010 base year US dollars (World Bank Data (2017)). The natural logarithm of GDP per person is shown in the form LOGGDP, and the natural logarithm of per person electricity consumption is shown in the form LOGELC. E-views 9 package program is used for econometric analysis.

In this study, the reason for the selection of 1980-2014 period as a sample is that the economic policies applied before 1980 and after 1980 was different. Liberalization policies implemented worldwide in 1980 directly affect electricity consumption and economic growth. Therefore, the time interval of the sample chosen in the study should be selected when global freedom is experienced in the world.

\section{APPLICATION}

\subsection{Unit Root Test Results}

Examining the graphical drawing before giving an econometric analysis of the series can give a preliminary idea of the series.

LOGGDP

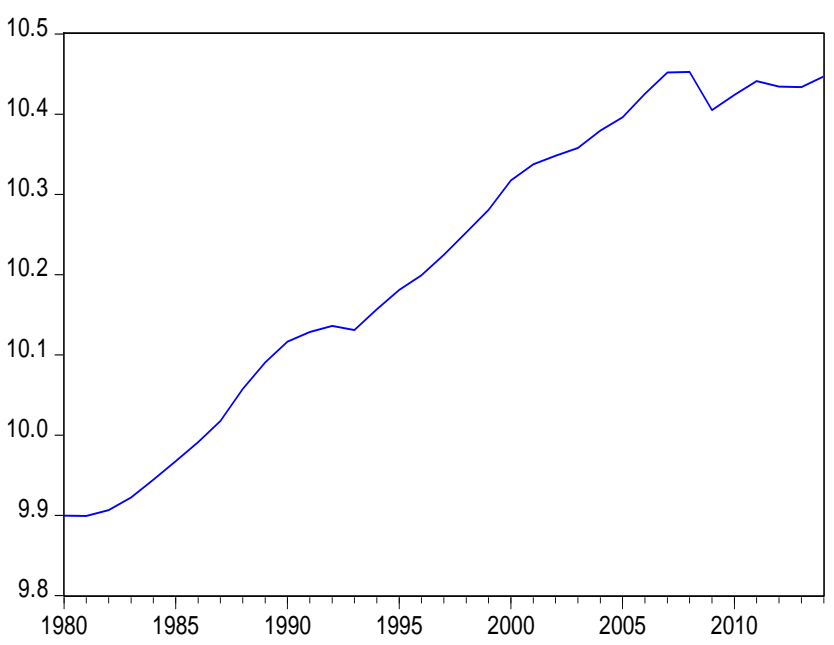

Figure 4: Graphical representation of the LOGGDP series for the period 1980-2014 in the EU. 
LOGELC

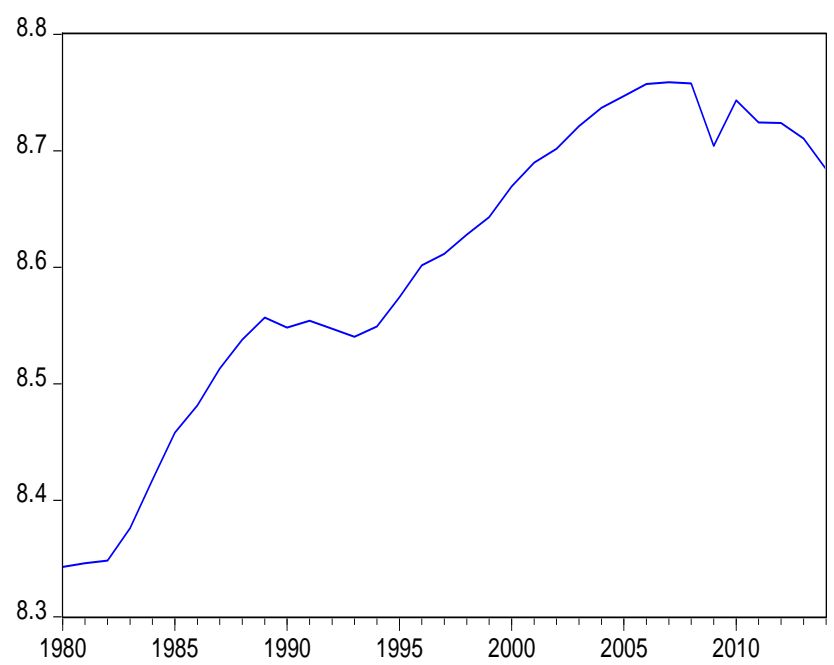

Figure 5: Graphical representation of the LOGELC series for the period 1980-2014 in the EU.

It is observed from Figure 4 and Figure 5 that the series tend to increase and have an increasing trend. For this reason, the series are not stationary at the level because they are not in constant advance and constant average.

ADF and PP unit root tests will be used to test the stability of the series. The results of these tests are shown in Table 3 and Table 4.

Table 3: ADF Unit Root Test Results

\begin{tabular}{|c|c|c|c|c|}
\hline \multicolumn{5}{|c|}{ ADF Unit Root Test Results } \\
\hline Variables & Features & Test Statistic & $\begin{array}{c}\text { Critical } \\
\text { Value } \\
(\% 1)\end{array}$ & $\begin{array}{c}\text { Critical } \\
\text { Value } \\
(\% 5)\end{array}$ \\
\hline \multirow{2}{*}{ LOGELC } & $\begin{array}{c}\text { Trend } \\
\text { and } \\
\text { Intercept }\end{array}$ & 0.2293 & $\begin{array}{c}- \\
4.252\end{array}$ & -3.548 \\
\hline & Intercept & -2.6693 & $\begin{array}{c}- \\
3.639\end{array}$ & -2.951 \\
\hline \multirow{2}{*}{ LOGGDP } & $\begin{array}{l}\text { Trend } \\
\text { and } \\
\text { Intercept }\end{array}$ & -0.1013 & 4.252 & -3.548 \\
\hline & Intercept & -1.6404 & $\begin{array}{c}- \\
3.639\end{array}$ & -2.951 \\
\hline \multirow{2}{*}{$\triangle$ LOGELC } & $\begin{array}{l}\text { Trend } \\
\text { and } \\
\text { Intercept }\end{array}$ & $-5.2649 *$ & 4. & -3.552 \\
\hline & Intercept & $-4.0844^{*}$ & $\begin{array}{c}- \\
3.646\end{array}$ & -2.954 \\
\hline \multirow{2}{*}{$\triangle \mathrm{LOGGDP}$} & $\begin{array}{l}\text { Trend } \\
\text { and } \\
\text { Intercept }\end{array}$ & $-4.3500 *$ & 4. & -3.552 \\
\hline & Intercept & $-3.9560 *$ & $\begin{array}{c}- \\
3.646\end{array}$ & -2.954 \\
\hline
\end{tabular}

Note: $\Delta$ represents the first difference operator. $*$ Represents $1 \%$ and ${ }^{* *}$ represents $5 \%$ significance.
Table 4: PP Unit Root Test Results

\begin{tabular}{|c|c|c|c|c|}
\hline \multicolumn{5}{|c|}{ PP Unit Root Test Results } \\
\hline Variables & Features & $\begin{array}{c}\text { Test } \\
\text { Statistic }\end{array}$ & $\begin{array}{c}\text { Critical } \\
\text { Value } \\
\text { (\%1) }\end{array}$ & $\begin{array}{c}\text { Critical } \\
\text { Value (\%5) }\end{array}$ \\
\hline \multirow{2}{*}{ LOGELC } & $\begin{array}{l}\text { Trend and } \\
\text { Intercept }\end{array}$ & 0.1944 & -4.252 & -3.548 \\
\hline & Intercept & -2.4526 & -3.639 & -2.951 \\
\hline \multirow{2}{*}{ LOGGDP } & $\begin{array}{l}\text { Trend and } \\
\text { Intercept }\end{array}$ & -0.1013 & -4.252 & -3.548 \\
\hline & Intercept & -1.6404 & -3.639 & -2.951 \\
\hline \multirow[t]{2}{*}{$\triangle$ LOGELC } & $\begin{array}{l}\text { Trend and } \\
\text { Intercept }\end{array}$ & $-5.2788^{*}$ & -4.262 & -3.552 \\
\hline & Intercept & $-4.2900^{*}$ & -3.646 & -2.954 \\
\hline \multirow{2}{*}{$\triangle$ LOGGDP } & $\begin{array}{l}\text { Trend and } \\
\text { Intercept }\end{array}$ & $-4.2548^{* *}$ & -4.262 & -3.552 \\
\hline & Intercept & $-3.9910^{*}$ & -3.646 & -2.954 \\
\hline
\end{tabular}

Note: $\Delta$ represents the first difference operator. ${ }^{*}$ Represents $1 \%$ and ** represents $5 \%$ significance.

In order to understand whether the series is stationary, the critical value and the test statistic value are compared within the absolute value. If the calculated test statistic value is greater than the critical value, the result is that the series is stationary and in the other case it is not stable. According to the ADF and PP unit root test results in Table 3 and Table 4, the LOGELC and LOGGDP series are stationary at their first differences.

\subsection{ARDL Bound Test Results}

In the ARDL Bound Test Approach, the optimal lag length must be determined in first stage. The ARDL test determines the appropriate model according to the lowest value given by the information criteria. In this stage, the variables are tested with different lag combinations and the model with the lowest value according to the information criteria (AIC, SIC or HQ) is selected as the appropriate model (Akel and Gazel, 2014). 


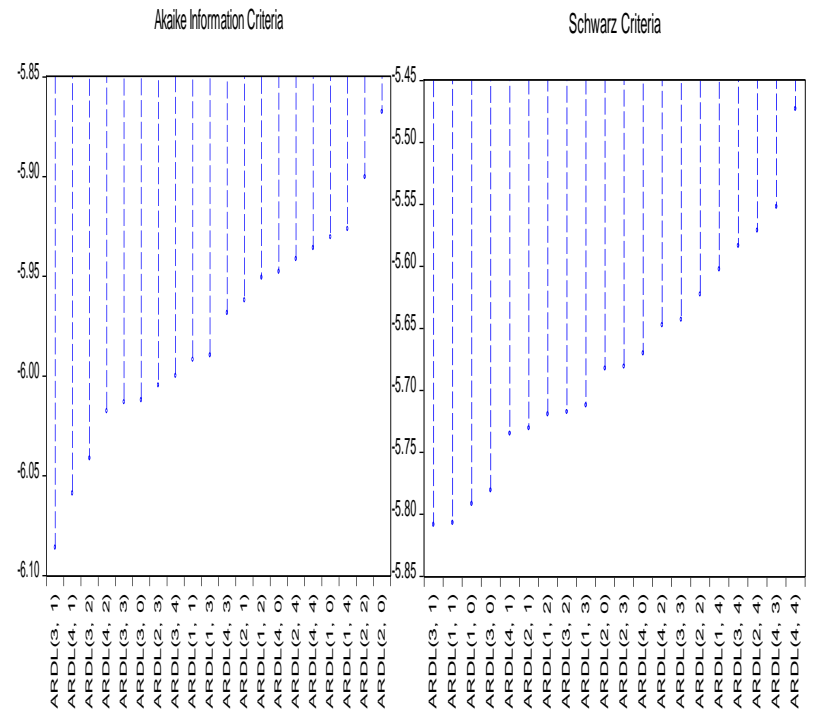

Figure 6: Model Selection Specification

Table 5: ARDL $(3,1)$ Model Estimation Results

\begin{tabular}{cccc}
\hline Variable & Coefficient & t-statistic & $\begin{array}{c}\text { Probability } \\
\text { Value }\end{array}$ \\
\hline LOGGDP(-1) & 1.032912 & 5.737819 & 0.0000 \\
LOGGDP(-2) & -0.494310 & -2.436630 & 0.0220 \\
LOGGDP(-3) & 0.296260 & 2.329257 & 0.0279 \\
LOGELC & 0.548715 & 5.061667 & 0.0000 \\
LOGELC(-1) & -0.296713 & -2.037462 & 0.0519 \\
CONSTANT & -0.468731 & -2.093198 & 0.0462 \\
\hline Diagnostic Test Results & & \\
\hline Breusch- & 0.787889 & Jarque- & 0.141953 \\
Godfrey Test & $(0.4662)$ & Bera Test & $(0.931484)$ \\
& 0.692429 & Ramsey & 2.258021 \\
ARCH Test & $(0.6048)$ & Reset Test & $(0.1455)$
\end{tabular}

Note: The values in parentheses in diagnostic test results indicate probability values.

Figure 6 shows that the ARDL $(3,1)$ model has the smallest value according to the AIC and SC information criteria and ARDL $(3,1)$ model is the most suitable model. The results of the selected model are shown in Table 5 . The Breusch-Godfrey test is testing autocorrelation, The Jarque-Bera test is testing normal distribution, The Arch Test is testing heteroskedasticity and The Ramsey Reset Test is testing to establishment of the model. The diagnostic test results presented in Table 5 demonstrate that there are no heteroskedasticity, autocorrelation and functional form problems in the model and the residuals exhibit a normal distribution.
Table 6: ARDL Bound Test Results

\begin{tabular}{ccc}
\hline \multicolumn{2}{c}{ 5.154146 } \\
\hline \multicolumn{3}{c}{ Critical Value Limits } \\
\hline Significance & Lower Limit & Upper Limit \\
$\% 1$ & 4.94 & 5.58 \\
$\% 2,5$ & 4.18 & 4.79 \\
$\% 5$ & 3.62 & 4.16 \\
$\% 10$ & 3.02 & 3.51 \\
\hline
\end{tabular}

The results of the ARDL bound test in Table 6 show that $\mathrm{F}$ statistic has a value greater than the upper limit of $5 \%$ critical value. It has a value beyond the critical border in $\% 5$ significance. In this case, bound test results shows that there is a long term cointegration relationship between electricity consumption and economic growth. So, there is a long-run equilibrium relationship was detected between the variables.

In the ARDL model, it is necessary to examine the long-run coefficients between the variables to determine size of the relationship. The longterm coefficients of the variables in the ARDL $(3,1)$ model are shown in Table 7.

Table 7: ARDL $(3,1)$ Model Long Term Coefficients (dependent variable LOGGDP)

\begin{tabular}{cccc}
\hline Variable & Coefficient & T-statistics & $\begin{array}{c}\text { Probability } \\
\text { Value }\end{array}$ \\
\hline LOGELC & 1.526007 & 12.757754 & 0.0000 \\
C & -2.838418 & -2.756805 & 0.0105 \\
\hline
\end{tabular}

According to the results presented in Table 7, the long term coefficient of the electricity consumption variable is positive and significant. This result means that electricity consumption has a positive effect on economic growth. It can be said that a $1 \%$ increase in electricity consumption will increase economic growth by $1.52 \%$.

The fact that the error correction term (ECM) has statistically significant and negative values indicates that the short cyclic equilibrium deviations will be corrected in the long run. The rate of achieving long-term equilibrium depends on the value of the error correction term. The results of the error correction mechanism including the short term dynamics of the ARDL $(3,1)$ model are presented in Table 8. 
Table 8: Error Correction Model Results

\begin{tabular}{cccc}
\hline Variable & Coefficient & $\begin{array}{c}\text { T- } \\
\text { Statistics }\end{array}$ & $\begin{array}{c}\text { Probability } \\
\text { Value }\end{array}$ \\
\hline$\Delta$ LOGGDP(-1) & 0.198050 & 1.5380 & 0.1361 \\
$\Delta$ LOGGDP(-2) & -0.296260 & -2.4219 & 0.0227 \\
$\Delta$ LOGELC & 0.548715 & 6.3638 & 0.0000 \\
ECM(-1) & -0.165138 & -4.0806 & 0.0004 \\
\hline
\end{tabular}

Note: $\Delta$ is difference operator. Values in parentheses indicate the number of lags.

In table 8, the output of the ECM in the range of -1 and 0 indicates that the error correction mechanism is working in model. This situation indicates that if there is a deviation from equilibrium in the short run, it will be restored to equilibrium in the long run. According to the results, ECM in the model was calculated as 0.165138. The term $\frac{1}{|E C M|}=\frac{1}{|-0.165138|}$ corresponds to approximately 6,05 period. As a result, we can say that the short-term equilibrium deviations will again be closer to the long-term equilibrium after the 6.05 period. In other words, short-term deviations will approach the long-term equilibrium at $16.51 \%$ in each period (Aydın and Bozdag, 2017).

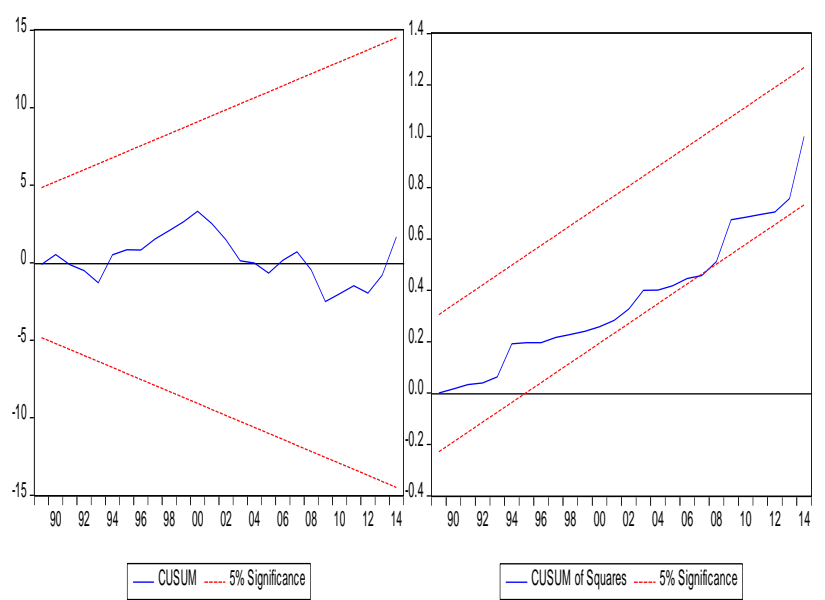

Figure 7: Cusum and Cusum of Squares Test Results

The Cusum Test and Cusum of Squares Test which is testing the suitability of short and long term coefficients and the stability of the predicted ARDL model. So, the robustness of the empirical analysis is tested by Cusum testing. The Figure 7 shows that the Cusum and Cusum of Squares test statistics remain within the critical limits at the $5 \%$ level of significance. This indicates that the estimated parameters are stable during the studied period (Alper and Alper, 2017).

\subsection{Toda-Yamamoto Causality Analysis Results}

It is necessary to know the values of the maximum stagnation degree $d_{\max }$ and the appropriate lag length $(\mathrm{m})$ for the TodaYamamoto causality test. The $d_{\max }$ value is 1 because the series are stationary in their first difference. The appropriate lag length $(\mathrm{m})$ is estimated from the VAR model with the assistance of information criteria.

Table 9: VAR Model Lag Length Estimates

\begin{tabular}{ccccccc}
\hline Lag & LogL & LR & FPE & AIC & SC & HQ \\
\hline 0 & -376.90 & NA & $1.95 \mathrm{e}+09$ & 27.06482 & $27.15997^{*}$ & $27.0939^{*}$ \\
1 & -374.45 & 4.378566 & $2.18 \mathrm{e}+09$ & 27.17539 & 27.46086 & 27.2626 \\
2 & -367.47 & $11.46541^{*}$ & $1.77 \mathrm{e}+09^{*}$ & $26.96260^{*}$ & 27.43839 & 27.1080 \\
3 & -364.64 & 4.251261 & $1.95 \mathrm{e}+09$ & 27.04588 & 27.71198 & 27.2495 \\
4 & -360.80 & 5.212291 & $2.02 \mathrm{e}+09$ & 27.05726 & 27.91368 & 27.3190 \\
5 & -358.35 & 2.969376 & $2.36 \mathrm{e}+09$ & 27.16831 & 28.21504 & 27.4883 \\
6 & -351.69 & 7.138155 & $2.08 \mathrm{e}+09$ & 26.97814 & 28.21519 & 27.3563 \\
\hline
\end{tabular}

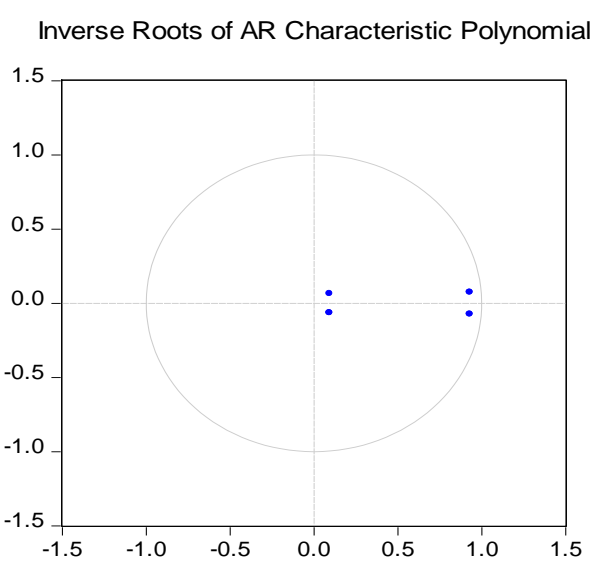

Figure 8: Unit circle of inverse roots of the AR polynomial

The values marked with * in Table 9 refer to the appropriate lag length. The second lag length is the appropriate lag length indicated by the AIC and the other two information criteria. For this reason, the value of $m$ is 2 in the Toda-Yamamoto causality analysis. 
Table 10: Toda-Yamamoto Causality Test Results

\begin{tabular}{cccc}
\hline Hypotheses & $\begin{array}{c}\text { Lag Length } \\
\mathbf{m = 2}, \boldsymbol{d}_{\text {max }}=\mathbf{1}\end{array}$ & $\boldsymbol{X}^{\mathbf{2}}$ Statistics & $\begin{array}{c}\text { Probabilit } \\
\mathbf{y} \text { Value }\end{array}$ \\
\hline $\mathrm{EC} \rightarrow \mathrm{GDP}$ & 3 & 4.8940 & 0.0866 \\
$\mathrm{GDP} \rightarrow \mathrm{EC}$ & 3 & 4.2477 & 0.1196 \\
\hline
\end{tabular}

In the Toda-Yamamoto causality test, the $H_{0}$ hypothesis states that there is no causality between variables while the $H_{1}$ hypothesis implies causality. According to the results in Table 10 , the $H_{0}$ hypothesis which means that there is no causality from the consumption of electricity to economic growth is rejected at the level of $10 \%$ significance. In this case, the Toda-Yamamoto test results show that there is unidirectional causality from electricity consumption to economic growth.

\section{Conclusion}

In the study, findings from the ARDL method show that electrical energy consumption in the European Union has a positive and significant impact on economic growth in the long-run. The results of the Toda-Yamamoto causality analysis confirm the Growth Hypothesis that advocates a unidirectional causality relationship from electricity consumption to economic growth based on the energy concept supported by ecological economists. According to this hypothesis, energy restrictive policies are not applicable because they create destructive results on economic growth.

As in the general literature, long-term relationship between the variables was determined also in this study. According to the long-term coefficients of ARDL, $1 \%$ increase in the consumption of electricity increases the economic growth by $1.52 \%$. In addition, the result of negative value constant term shows that there will be economic recession in the absence of electrical energy. In the TodaYamamoto test results, unidirectional causality has shown that electrical energy is a cause of economic growth. This ultimately proves that electricity is a great need for economic growth.

In the case where the Growth Hypothesis is valid, it can be deduced that the economy is dependent on energy. In these economies, energy will be stimulated for economic growth or a potential energy shock will adversely affect economic growth. Energy shocks could also cause a decline in income and employment. The European Union mostly uses imported resources in electricity generation. In the European Union, imported natural gas is used in electricity supply at a rate of $16.4 \%$. In addition, the import rates of other energy sources used in electricity supply in the European Union are quite high. High dependence on foreign energy also threatens energy supply security. The most important policies to be implemented for the European Union are to reduce dependence on foreign energy and increase the diversity of resources used in electricity supply.

Considering that electricity consumption is the cause of economic growth, policy makers should be careful about the electricity prices and taxes imposed on electricity. Since an increase in electricity prices and taxes is a cost element, it will bring down production and reduce economic growth. For such reasons, it is recommended that policy makers be careful when implementing energy conservation policies in the European Union. 


\section{REFERENCES}

Acaravci, A. and Ozturk, I. (2010). Electricity consumption-growth nexus: Evidence from panel data for transition countries. Energy Economics, 32, 604-608.

Ağır, H. and Kar, M. (2010). Türkiye'de Elektrik Tüketimi ve Ekonomik Gelişmişlik Düzeyi İlişkisi: Yatay Kesit Analizi. Sosyo Ekonomi, Özel Sayı 2010-EN, 149-176.

Akel, V. and Gazel, S. (2014). Döviz Kurları İle Bıst Sanayi Endeksi Arasındaki Eşbütünleşme İlişkisi: Bir Ardl Sınır Testi Yaklaşımı. Erciyes Üniversitesi İktisadi ve İdari Bilimler Fakültesi Dergisi 44, 23-41.

Akinlo, A. E. (2009). Electricity consumption and economic growth in Nigeria: Evidence from cointegration and co-feature analysis. Journal of Policy Modeling, 31, 681-693.

Alper, F. Ö. and Alper, A. E. (2017). Karbondioksit Emisyonu, Ekonomik Büyüme, EnerjibTüketimi İlişkisi: Türkiye İçin Bir ARDL Sınır Testi Yaklaşımı. Sosyoekonomi, 25(33), 145-156.

Atif, S. M. and Siddiqi, M. W. (2010). The Electricity Consumption and Economic Growth Nexus in Pakistan: A New Evidence. Munich Personal RePEc Archive 2010; Working Paper No: 41377.

Aydın, B. and Bozdağ, E. G. (2018). Elektrik Tüketimi ve Ekonomik Büyüme Arasındaki Ilişki: Avrupa Birliği ve Türkiye Örneği, International Journal of Academic Value Studies, 4(18), 70-80.

Bah M. M. and Azam, M. (2017). Investigating the relationship between electricity consumption and economic growth: Evidence from South Africa. Renewable and Sustainable Energy Reviews, 80, 531-537.

Bélaïd, F. and Abderrahmani, F. (2013). Electricity consumption and economic growth in Algeria: A multivariate causality analysis in the presence of structural change. Energy Policy, 55, 286-295.
Bohm, D. C. (2008). Electricity consumption and economic growth in the European Union: A causality study using panel unit root and cointegration analysis, 2008 5th International Conference on the European Electricity Market, Lisboa, 2008, pp. 1-6, doi: 10.1109/EEM.2008.4579055.

Ciarreta, A. and Zarraga, A. (2010). Economic Growth and Electricity Consumption in 12 European Countries: A Causality Analysis Using Panel Data. Energy Policy, 38, 37903796.

Ciarreta, A. and Zarraga, A. (2007). Electricity Consumption and Economic Growth: Evidence from Spain. Documentos De Trabajo Blltokl, 01, 1-16.

Ergün, S. ve Atay Polat, M. (2015). OECD Ülkelerinde Co2 Emisyonu, Elektrik Tüketimi ve Büyüme İlişkisi. Erciyes Üniversitesi İktisadi ve İdari Bilimler Fakültesi Dergisi, 45, 115-141.

European Commission (2019). European Commission statistical country datasheets. Date of Access: February 24, 2019. https://ec.europa.eu/energy/en/data/energy -statistical-pocketbook.

Gazel, S. (2017). Bist Sınai Endeksi İle Çeşitli Metaller Arasındaki İlişki: Toda-Yamamoto Nedensellik Testi. Akademik Sosyal Araştırmalar Dergisi, 52, 287-299.

Ghosh, S. (2002). Electricity consumption and economic growth in India. Energy Policy, 30, 125-129.

Gujarati, D. N. and Porter, D. C. (2009). Temel Ekonometri (Çev. Ü. Şeneşen ve G. G. Şeneșen). İstanbul: Litaretür Yayınları No 656. (Eserin orjinali 5. Baskıdan Çeviri).

Hamdi, H. and Sbia, R. (2012). Short-run and Long-run causality between electricity consumption and economic growth in a small open economy. Munich Personal RePEc Archive 2012; Working Paper No: 49904. 
Ikegami, M. and Wang, Z. (2016). The long-run causal relationship between electricity consumption and real GDP: Evidence from Japan and Germany. Journal of Policy Modeling, 38, 767-784.

International Energy Agency (2017). International Energy Agency Data. Date of Access: November 15, 2017. https://www.iea.org/.

Kayhan, S., Adığüzel, U., Bayat, T. and Lebe, F. (2010). Causality Relatıonshıp Between Real Gdp And Electricity Consumption In Romania (2001-2010). Romanian Journal of Economic Forecasting, 4, 169-183.

Narayan, P. K. and Smyth, R. (2005). Electricity consumption, employment and real income in Australia evidence from multivariate Granger causality tests. Energy Policy, 33, 1109-1116.

Narayan, P. K., Narayan, S. and Prasad, A. (2008). A structural VAR analysis of electricity consumption and real GDP: Evidence from the G7 countries. Energy Policy, 36, 2765-2769.

Nişancı, M. (2005). Türkiye'de Elektrik Enerjisi Talebi ve Elektrik Tüketimi ile Ekonomik Büyüme Arasındaki İlişki. Selçuk Üniversitesi İktisadi ve İdari Bilimler Fakültesi Sosyal ve Ekonomik Araştırmalar Dergisi, 5(9), 107-121.

Osman, M., Gachino, G. and Hoque, A. (2016). Electricity consumption and economic growth in the GCC countries: Panel data analysis. Energy Policy, 98, 318-327.

Pamuk, M., ve Bektaş, H. (2014). Türkiye'de Eğitim Harcamaları ve Ekonomik Büyüme Arasındaki İlişki: ARDL Sınır Testi Yaklaşımı. Siyaset, Ekonomi ve Yönetim Araştırmaları Dergisi, 2(2), 77-90.

Payne, J. E. (2010). A survey of the electricity consumption-growth literatüre. Applied Energy, 87, 723-731.

Peter Sekantsi, L. and Motlokoa, M. (2015). Evidence On The Nexus Between Electricity Consumption and Economic Growth Through Empirical Investigation of Uganda. Review of Economic \& Business Studies, 8(1), 149-165.
Shahbaz, M., Sbia, R., Hamdi, H. and Ozturk, I. (2014). Economic growth, electricity consumption, urbanization and environmental degradation relationship in United Arab Emirates. Ecological Indicators, 45, 622-631.

Shahbaz, M., Tang, C. F. and Shahbaz Shabbir, M. (2011). Electricity consumption and economic growth nexus in Portugal using cointegration and causality approaches. Energy Policy, 39, 3529-3536.

Shiu, A., and Lam, P.-L. (2004). Electricity consumption and economic growth in China. Energy Policy, 32, 47-54.

Squalli, J. (2007). Electricity consumption and economic growth: Bounds and causality analyses of OPEC members. Energy Economics, 29, 1192-1205.

Tang, C. F. (2008). A re-examination of the relationship between electricity consumption and economic growth in Malaysia. Energy Policy, 36, 3077-3085.

Toda, H. Y. and Yamamoto, T. (1995). Statistical İnference in Vector Autoregressions With Possibly İntegrated Processes. Journal of Econometrics, 66, 225-250.

World Bank Data (2017). World Bank Indicators. Date of Access: November 15, 2017. https://data.worldbank.org/.

Wolde-Rufael, Y. (2006). Electricity consumption and economic growth: a time series experience for 17 African countries. Energy Policy, 34, 1106-1114.

Yoo, S. H. (2006). The causal relationship between electricity consumption and economic growth in the ASEAN countries. Energy Policy, 34, 3573-3582.

Yoo, S.-H. (2005). Electricity consumption and economic growth: evidence from Korea. Energy Policy, 33, 1627-1632. 